\title{
POSSIBILITIES OF THE PRACTICAL APPLICATION OF REMOTE SENSING DATA IN REAL PROPERTY APPRAISAL
}

\author{
Rafał Dąbrowski, M.Sc. \\ Faculty of Civil Engineering and Geodesy \\ Military University of Technology, Warsaw, Poland \\ e-mail:dabrowski@wat.edu.pl \\ Dorota Latos, M.Sc. \\ Faculty of Civil Engineering and Geodesy \\ Military University of Technology, Warsaw, Poland \\ e-mail:dlatos@wat.edu.pl
}

\begin{abstract}
In the process of real estate evaluation, there are many important elements that should be taken into consideration: for example the type of property which is under evaluation, real estate market analysis, and the selection of appropriate evaluation approaches, methods and techniques. In each of the approaches, different parameters are important. Most importantly, however, is the appropriate selection and identification of real estate characteristics, both physical and economic, as well as the determination of the importance of these qualities so that, when necessary, it will be possible to make the appraisal and select those characteristics which have the greatest impact on value of property.

To acquire information about real estate, one can analyze data from multiple sources of information, such as: the land and mortgage register, land and buildings register, local town and country planning, industry data and other. Integrating data from all these sources allows comprehensive and up-to-date knowledge on the assessed property to be developed.

One of best sources of data describing the characteristics of real estate is remote sensing. This method offers a high spectrum of information and, therefore, allows a wide range of analyses. As a result, one can obtain highly accurate facts about the property. Remote sensing data, however, are not a panacea for all problems and have some limitations that determine their applicability.

This paper describes the possibilities of specifying some characteristics of the property under appraisal based on remote sensing data. For this purpose, the qualitative - quantitative analysis of the four most "common" types of remote sensing data were made, along with determining selected characteristics of 30 properties located in the Warsaw - Bemowo suburb area.

The results of this research made it possible to answer the question of whether it is practicable and, if so, to what extent, to use remotely sensed data as the basis for determining the characteristics of a property as well as connecting the types of data to individual properties. The paper focuses on defining the characteristics of two kinds of real estate: land and buildings.
\end{abstract}

Key words: physical characteristics of real estate, remote sensing data, data interpretation.

JEL Classification: R30, C83.

Citation: Dąbrowski R., Latos D., 2015, Possibilities of practical application of the remote sensing data in the real property appraisal, Real Estate Management and Valuation, Vol. 23, No. 2, pp. 65-73.

10.1515/remav-2015-0016 


\section{Introduction}

The most important physical characteristics of real estate are: physical complexity, consistency of its geographic location, permanency, diversity and indivisibility. Meanwhile, the main economical characteristics are: rarity, localization in terms of the surroundings/neighborhoods, interdependence, high capital-intensiveness, and low financial liquidity. Each of these features can have a different impact on the value of real property. The impact of individual features/characteristics can also be different depending on the diversity of a particular real estate market or buyers' preferences.

In order to assess the impact of selected characteristics of real estate on its value, one should take advantage of the availability of data from many different sources in order to obtain the most complete information about a given property. This should include data from: the land and mortgage register, land and buildings register, local town and country planning documents, industry data and other sources. Examining the contents of most of them is a mandatory step in verifying the real estate data; other sources can be used as long as they increase knowledge on the subject of the appraisal.

With information specifying the location of the property, one can make a preliminary assessment of its characteristics using remote sensing data. Due to their nature (and proper level of reliability and validity), remote sensing datasets are appropriate for use in real estate appraisal processes as well as having a broad spectrum of other applications (CHUVIECO 1989; METTERNICHT, HURNI, GOGU 2005; BENDIG, BOLTEN 2012).

These data are obtained by means of remote sensing sensors (passive and active) recording the energy reflected from the object (phenomenon) or emitted by an object in different ranges of the electromagnetic spectrum. Different types of remote sensing data, due to their nature, have varying potential of photo-interpretation (for example, regarding resolution: spatial, radiometric, temporal and spectral), which directly corresponds to the possibility of their use as a source of information about real estate. This topic was discussed in the following works: RYAN at el. 2003; DABROWSKI, ORYCH, WALCZYKOWSKI 2010; DABROWSKI, ORYCH, WALCZYKOWSKI 2013.

In the initial phase of the valuation of the property characteristics, different remote sensing data can be used: aerial photographs, satellite images, LIDAR data, multi- and hyperspectral data. However, the most common type of remote sensing data used in the property assessment process are datasets available in the form of digital images obtained using different ranges of the electromagnetic spectrum from sensors placed on moving platforms flying at different heights. Based on this data, one can specify parameters, such as: the approximate shape and size of the plot, the number of buildings on the property, land use, and even (under certain boundary conditions) the number of storeys of a building and its technical condition.

This paper presents an analysis of the applicability of remote sensing data to conduct a preliminary assessment of selected physical characteristics of real estate.

\section{Characteristics and attributes of real estate}

The real estate market, if analyzed against the regulations contained within the Civil Code, is divided into: land, buildings and premises (this is known as the primary subdivision of real estates). If analyzed further in accordance with this fragmentation, one can distinguish a number of characteristics that allow each of the different types of real estate to be described. The basis for determining the market value of a property is the selection of such features which have the greatest impact on the value. Proper identification of the impact of these characteristics on the value of the property allows to set criteria on the basis of which one could determine real estate market value.

Characteristics (according to the Dictionary of Foreign Words, PWN Publishing House, http://sjp.pwn.pl) are the elements characterizing the objects, their activities and conditions and phenomena (Radzewicz, Wisniewski 2012). Selected characteristics - attributed to real estate and grouped according to their type, have been shown in Table 1. However, if analyzed more closely (for example: building plots in urban areas of large cities), different choosing and grouping of the characteristics may apply (GAWRON 2012).

Characteristics of the property can be further refined by adding to each of them attribute values, which are the features of thing (people or phenomena) distinguishing them from others, without which they could not exist and fulfill their function (RADZEWICZ, WISNIEWSKI 2012). Assigning attribute values to each of the characteristics makes the real estate unique and recognizable. 
The area characteristic of the real property should correspond to the size of the plot (an extent defined in $\mathrm{m}^{2}$ ); localization is the position of the property in the city, district, (it could have such values as the outskirts, uptown, or downtown). The neighborhood attribute lists the immediate surroundings of the estate (subjectively important for potential buyers) such as churches, schools, nurseries, kindergartens, health centers, parks, forests, local availability of means of transportation, service outlets, retail outlets, manufacturers, etc.

Table 1

Sample list of the real estate characteristics

\begin{tabular}{|c|c|}
\hline Real estate type & Characteristics \\
\hline Land & $\begin{array}{l}\text { - area of the plot } \\
\text { - localization } \\
\text { - neighborhood } \\
\text { - shape } \\
\text { - land use and development condition } \\
\text { - type } \\
\text { - water condition } \\
\text { - local town and country planning use }\end{array}$ \\
\hline Building & $\begin{array}{l}\text { - area of the plot, building } \\
\text { - localization } \\
\text { - neighborhood } \\
\text { - number of storeys } \\
\text { - building equipment condition } \\
\text { - building technical equipment }\end{array}$ \\
\hline Premises & $\begin{array}{l}\text { - area of the plot, building, premises } \\
\text { - localization } \\
\text { - neighborhood } \\
\text { - type of premises } \\
\text { - fittings / final finishes standard } \\
\text { - building technology }\end{array}$ \\
\hline
\end{tabular}

Source: RADZEWICZ, WIŚNIEWSKI (2012, p. 9).

The shape may be regular, irregular; the land use and development condition can be filled by specifying the number of buildings on the property, information about the utilities/technical infrastructure of the plot, or identifying the existence of a fence. The type can determine whether the plot is built or unbuilt; the local town and country planning use indicates what purpose is intended for the real property (e.g.: industrial, housing, services, agriculture). As for the plot's water conditions - this characteristic may determine whether a property is located on wetlands, with a low/high groundwater level, or the proximity to watercourses or water bodies. The technical condition of a building can be described as very good, good, average, sufficient, poor, or unsafe.

Moreover, when defining real estate characteristics, it is important that particular aspects of specific features are further weighted depending on their impact on the value of the property (KOZIOŁKACZOREK 2012).

Differentiating betwen the impact of the individual characteristics of a property in the process of its appraisal is the topic of many studies. All of them, however, show a consistent pattern, from which it can be concluded that their overall impact on the value of a property is similar and will be more or less the save for the analyzed real estate makret (HARRIS, DONG, ZHANG 2013).

\section{Classic real property data sources}

"Information about the properties come from a variety of sources and contain different data. Some include the identification, location of the property, others describe the legal status, or they have information about the rent payment level, etc." (LATOS 2012). The data sources mentioned in the introduction of this paper allow much important information to be gained about all types of real estate (land, buildings, premises).

The land and mortgage registers contain mainly information on the legal status of the estate. Nevertheless, alogside entries about property rights or the personal data of an owner, there are also land and building registration data from which one could find out, among others: the localization and 
the neighborhood of the property, its area or function. This makes it possible to gather some information necessary to determine certain characteristics, which could next be crosschecked with data acquired, for example, from the land and buildings register (the Surveying and Cartography Law Act of 17.05.1989).

Other important documents relating to the real properties are maps (including basic maps, cadastral maps or property maps). On the basis of these maps, one can learn about the localization of a plot or building, the neighborhood, the land use and state of developmentas well as the shape or surface area.

Plenty of relevant information regarding the characteristics of real property is also included in the local town and country planning documentation. Not only do these documents present the intended use and manner of development established for a particular plot but, on top of this, one can also find information such as the minimum area of a building plot, maximum building area, existing and planned roads, and permitted height and function of buildings.

Much of the information associated with the characteristics of the real property development state, for instance regarding the condition and amount of technical equipment of a building, can be obtained from institutions managing utilities networks. They possess detailed information on the type of network they manage, from which one can find out about the state of the existing infrastructure as well as planned investments and repairs. Analyzing other industry data, one could evaluate the technical condition of the building, the year of construction, the type of materials from which it was made, the size of the building and availability of utilities, technical equipment, finishing standard, modernity, etc.

\section{Remote sensing data as a source of information in the process of determining the real estate characteristics}

\subsection{Research material}

The base materials used in the process of evaluating of the analyzed real estate were:

- multispectral satellite images - WoldVierw-2 system;

- digital aerial photographs obtained with UltrCAM camera;

- digital aerial photographs acquired with Sony Nex-5 camera from on board an Unmanned Aerial Vehicle (UAV);

- LiDAR (Light Detection and Ranging) Data, acquired in 2013.

The presented remote sensing data vary in terms of their properties and method of acquisition, and were selected so as to represent remote sensing data commercially available on the market.

In order to present the ability of assessing some aspects of real estate on the basis of remote sensing data, studies were carried out on a sample of 30 randomly selected, including 21 built-up and 9 undeveloped, plots of land located within the heart of Warsaw-Bemowo.

The analyzed properties appeared on the aftermarket (as advertisements on web pages) and, therefore, it was possible to obtain information about them, including the type, address, and much more. Due to the nature of the real estate market, mainly because of the possibility of purchasing property with a mortgage, it was highly likely that there would be a need to determine the value of these properties by a property appraiser.

\subsection{Research methodology}

Information regarding selected characteristics that could affect the value of the analyzed property was obtained on the basis of base material. Selected characteristics were determined by analyzing the quantitative - qualitative "raw", as well as the processed image data (ortho, spectral composition, vegetation indices), with photointerpretation techniques based on direct and indirect distinguishing characteristics, i.e.: color, size and shape of the object, texture and structure, shade and relationships between objects.

The detailed results for selected buildings and land real estate have been presented in the following subchapter. The localization and proximity of objects had been pre-determined based on address data obtained from public announcements and open web databases.

\subsubsection{Land real estate}

The first step in the analytical process was the spatial identification of property and its general 
characteristics in order to obtain information related to such features as proximity and localization. This process was done on the basis of "raw" aerial photos and satellite images. In view of the area presented in the images, this was a relatively simple task. The selected land real estate is all located in the one of Warsaw' districts - Bemowo, in direct contact with one of three streets, i.e.: Wrocławska, Powstańców Śląskich and Radiowa (Fig. 1.).

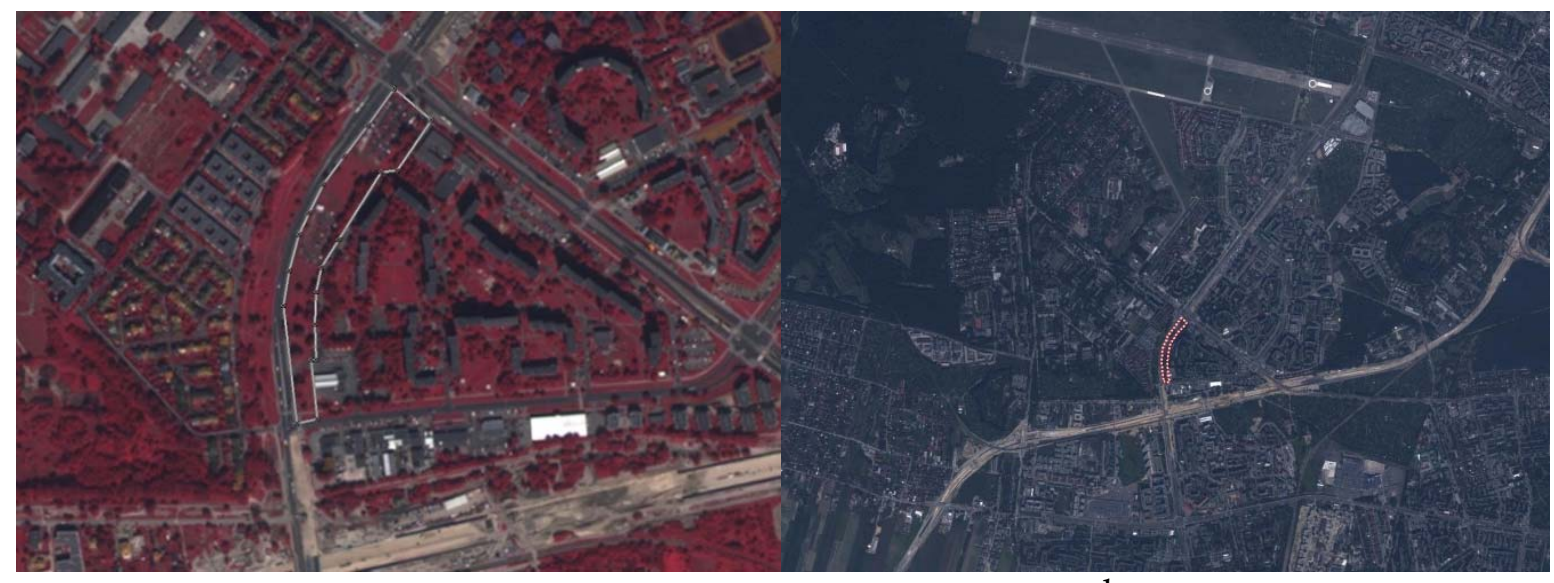

a

$\mathrm{b}$

Fig. 1. Visualization of the analyzed real estate on satellite falsecolor image (a) and on the natural color image (b). Source: Own study.

On the basis of the visual analysis, relying on direct and indirect defining features, a welldeveloped transport infrastructure and public transport infrastructure was confirmed in the immediate vicinity of the analyzed land property (Fig. 2a). For the surrounding land properties, a dynamic process of development (residential development - Fig. 2c, commercial development - Fig. $2 b)$ could be observed. At just 500 meters from the analyzed land real estate, there is a primary school, university $(800 \mathrm{~m})$ and sports and recreation areas $(2 \mathrm{~km})($ Fig. $2 \mathrm{~d})$.

The next step was to identify those aspects of the property that are associated with the need for the carrying out quantitative measurement. For that purpose orthophotomaps from satellite images, aerial photographs and LIDAR data were all used.

On the basis of quantitative analysis, it can be concluded that the selected land real estate is characterized by an irregular shape, the area of the plot is flat and amounts to approximately 2.3 ha, with a perimeter of about $1065 \mathrm{~m}$. The shape of the investigated real estate is determined by the Powstańców Śląskich street - an area $50 \mathrm{~m}$ wide and $480 \mathrm{~m}$ long (Fig. 1a).

Thanks to the information contained in the near-infrared spectral channel of the satellite image (Fig. 1 shows images in contractual colors - red pixels represent natural vegetation), it can be stated that approximately $70 \%$ of the property is covered with vegetation while the remaining $30 \%$ contains a fenced parking area with a gravel surface. In the perimeter of the real estate, there are no watercourses or water reservoirs. This information was confirmed with the use of LIDAR data.

\subsubsection{The building}

The analyzed building is also located in the Bemowo district of Warsaw, within an area defined by Radiowa and Sylwestra Kaliskiego streets, a short distance from the analyzed land property. For that reason, the neighborhood of the building is substantially the same as that described for the land real estate. The differences relate only on the proximity of an airport for small planes and gliders, located just $300 \mathrm{~m}$ from the investigated building. This information was obtained from both "raw" aerial and satellite images.

On the basis of the orthoimage from aerial photographs, it was determined that the building is takes on the form of rectangular structurewith horizontal dimensions of $82.6 \times 18.3$ meters. The surface of the building is approximately $1500 \mathrm{~m}^{2}$. Information on the height of the building may be obtained directly by analysis of LIDAR data, or estimated from inclined photographs acquired from the UAV. The analyzed building is about $10 \mathrm{~m}$ in height and has a hipped roof covered with roofing paper. 

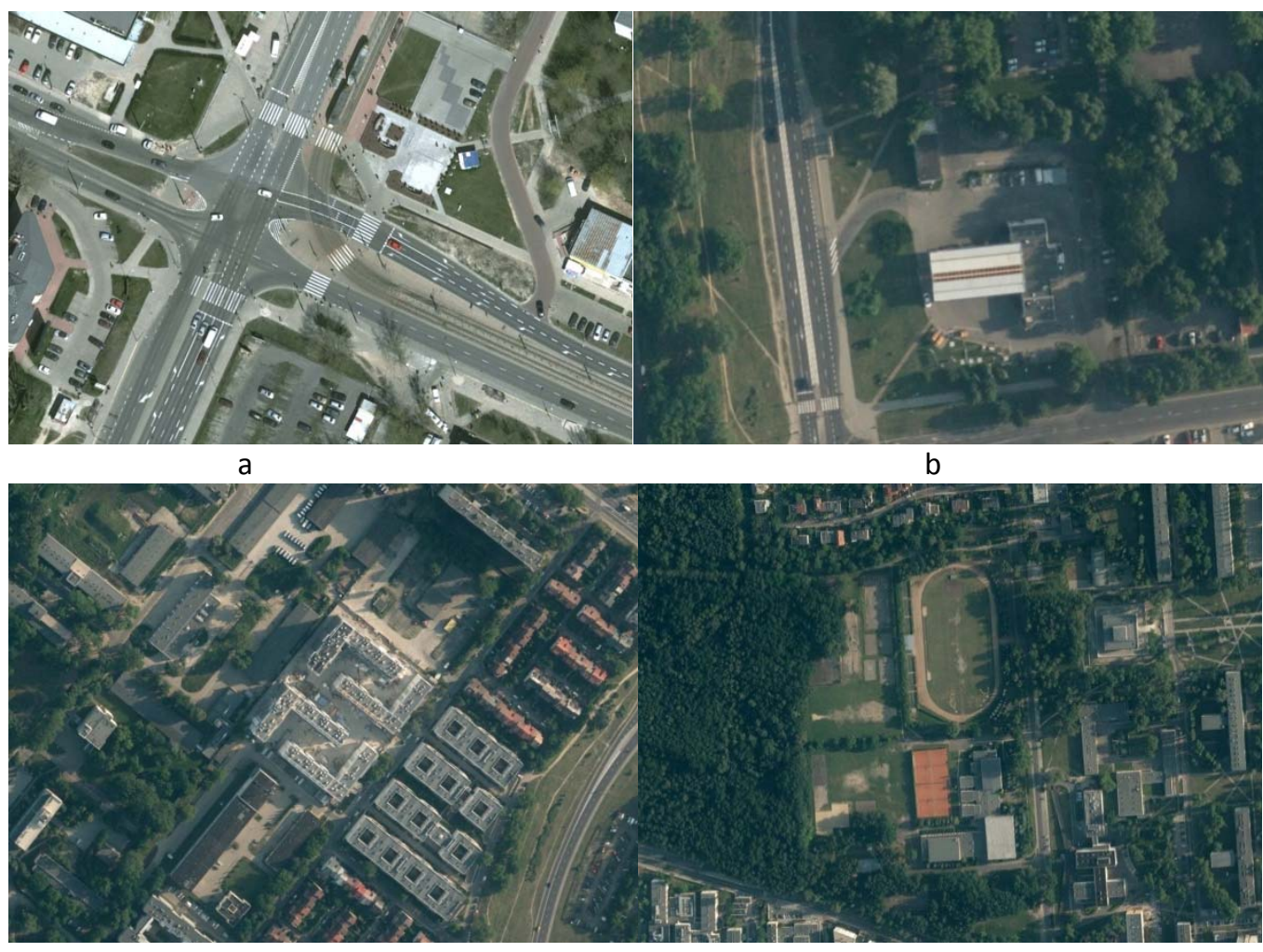

c

d

Fig 2. Area in the closest proximity of the selected real estate. Elements of the transport infrastructure and public transport (a), the residential development $(b, c)$, sport and recreation infrastructure (d). Source: Own study.

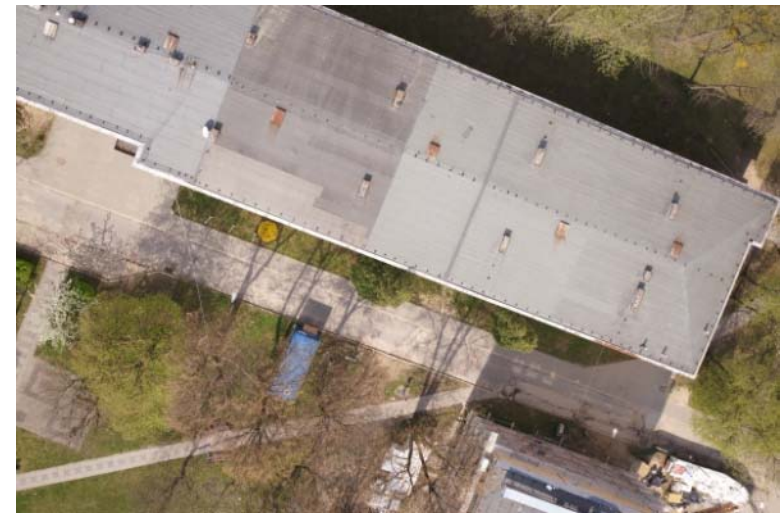

a

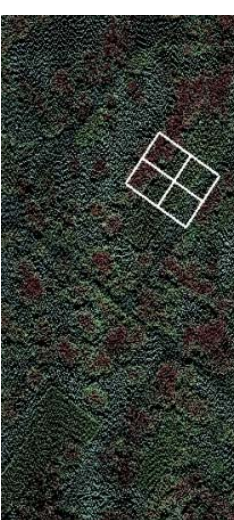

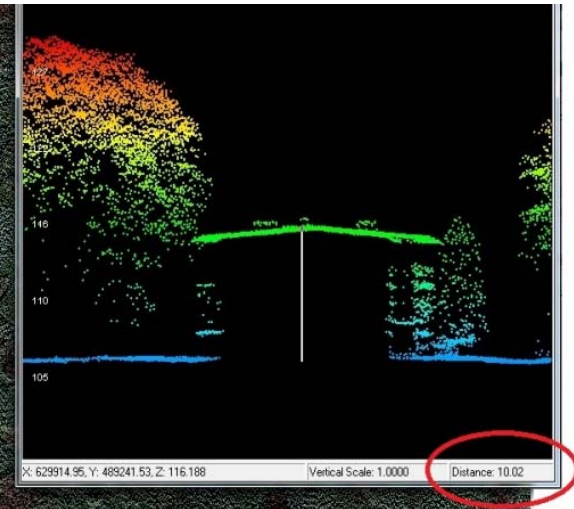

b

Fig. 3. Images of analyzed building acquired from the UAV (a) and LIDAR data (b). Source: Own study.

In addition, using high spatial resolution of orthoimages from the UAV, the preliminary assessment of the technical condition of selected elements of the roof of the building was made possible. Roofing elements, lightning protection, etc. are perfectly visible (Fig. 4).

\section{Discussion of results}

The carried out research process enabled the extraction of remote sensing data that can be used to determine certain characteristics of analyzed property. The analysis was performed on land and building real estate. The premises of real estate, due to being located on the inside of buildings, may have certain specific features; however, these are directly related to the buildings in which they are located and were therefore not included in the analysis. 


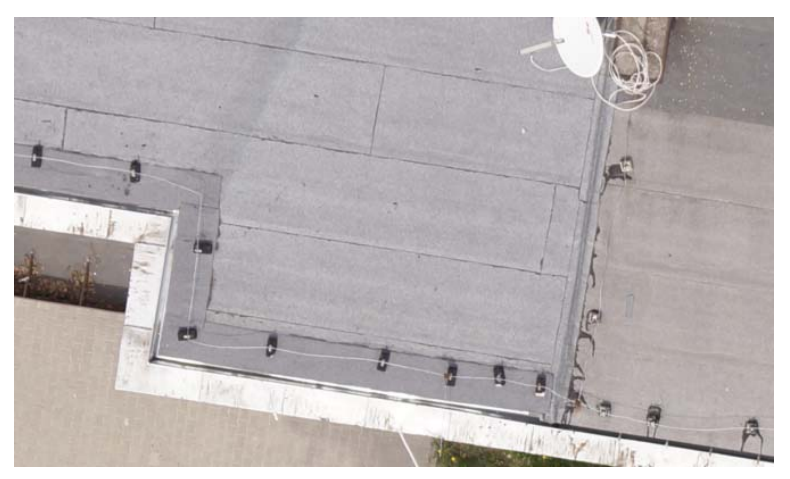

Fig. 4. Fragment of an image of the analyzed building derived from sensor mounted on a UAV. Source: Own study.

A summary of the results has been presented in Table 2 and shows the characteristics which can be possible, impossible or conditionally possible to determine on the basis of selected remote sensing data. The physical characteristics of the property were related to the distribution shown in Table 1.

Table 2

Real estate attributes possible to identify on the basis of remote sensing data

\begin{tabular}{|c|c|c|c|c|c|c|c|c|c|c|c|c|c|}
\hline \multirow{2}{*}{$\begin{array}{l}\text { Data / } \\
\text { elaboration type }\end{array}$} & \multicolumn{6}{|c|}{ Building Real Estate } & \multicolumn{7}{|c|}{ Land Real Estate } \\
\hline & 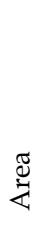 & 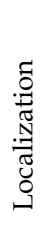 & 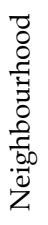 & 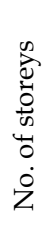 & 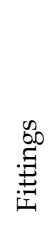 & 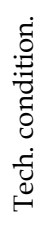 & $\underset{巳}{2}$ & 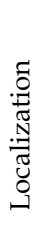 & 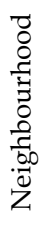 & 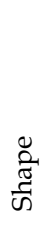 & 芯 & 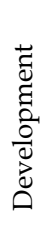 & 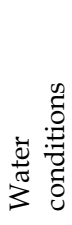 \\
\hline Orthophoto & + & + & + & $+/-$ & - & $+/-$ & + & + & + & + & $+/-$ & + & + \\
\hline $\begin{array}{l}\text { "Raw" satellite and aerial } \\
\text { images }\end{array}$ & - & + & + & $+/-$ & - & $+/-$ & - & + & + & + & $+/-$ & + & + \\
\hline $\begin{array}{l}\text { "Raw" images from an } \\
\text { UAV }\end{array}$ & - & + & + & + & $+/-$ & + & - & + & + & + & + & + & + \\
\hline LiDAR Data & + & + & + & $+/-$ & - & $+/-$ & + & + & + & + & $+/-$ & $+/-$ & $+/-$ \\
\hline
\end{tabular}

Source: Own study.

In the table, the "+" symbol indicates those attributes that can be determined on the basis of different types of remote sensing data. The "+ / - " means that the feature is possible to determine under certain boundary conditions. The symbol "-" means that there is no possibility of identifying the given feature.

When analyzing this table, it can be seen that orthophotos have the widest application in determining the set out features of real estate. With their use, it is possible to determine most features of building and land real estate. By combining cartometric maps and the information capacity of aerial photos, it is possible to determine the quantitative and qualitative characteristics of property. Depending on the spatial resolution of an orthophoto, the level of the possible extraction of information varies. Additionally, it is possible to increase the information potential of orthophotos by adding a thematic layer, obtained via digital image processing (i.e. vegetation indices, spectral composition), which makes it possible to detect and enhance the boundaries and contours of objects on the image.

"Raw" aerial images due to their characteristics can only be used to evaluate real estate features derived from quantitative measurements. However, the use of inclined and oblique images (more often performed for civil purposes) in an extremely simple way that enables us to obtain information on the number of storeys of building real estate, the technical condition of the facade and, in the case of land real estate, is perfect for determining data regarding land development.

When features of building real estate are being determined, useful remote sensing data can be acquired from UAV sensors. These are characterized above all by high spatial resolution which translates to the ability to reliably assess the technical condition of buildings, e.g. the condition of 
roofing elements, and in the case of UAVs constructed in rotorcraft convention, also the technical condition of the facade.

LiDAR data are used to determine all of the analyzed features of land real estate and the majority of those for building properties (i.e. accurate determination of building height).

\section{Summary and conclusions}

The basis for determining the value of real property is to identify such characteristics/attributes, which have the greatest impact on the overall value of the property. The correct identification and determination of the strength of influence of these characteristics allows to set criteria with which it is possible to calculate the precise value of the real estate. This requires a series of analyses, studies, aquiring large amounts of data, and visual evaluation of the property.

An alternative to the classic sources of information about the property, are remotely sensed data. Using such data, one can determine, in a relatively simple way, many characteristics of the property under appraisal. Information obtained in this way, is marked with a high degree of validity and credibility. In addition, with access to image data obtained at different intervals of time, it is possible to perform multi-temporal analyses in the context of changes in the characteristics of the property (such as the environment surrounding the plot) and the impact of these changes on the value of the property (DIN, HOESLI, BENDER 1997).

Remote sensing data, however, are not a panacea for all the problems and also have limitations, some of which are shown here in the discussion of research results. These limitations are primarily determined by the properties and acquisition methods of different types of remote sensing data and, in a direct way, correspond to the level of potential applications in the context of determining the characteristics of the property. Striking examples are: image data obtained from an UAV, which allows fpr detailed analysis, or an inclined photo which allows the acquisition of such attributes as information about the properties of the building facade; however, both of them cover only a very small area of land.

Another disadvantage of remote sensing data is the relatively high cost of obtaining the material and the need for appropriate software for its further digital processing. Acquiring image data or a product developed on the basis of such data brings high cost into a play, however, in return give the possibility of making a series of highly reliable quality-quantitative analyses when it comes to the evaluation of the physical characteristics of real estate.

This problem can be solved by using open sources of information from which a wide range remote sensing data types of varying information potential can be obtained.

In conclusion, in order to complete property appraisal in a correct way, one can use the potential of remote sensing datasets at any stage of the appraisal process. This approach corresponds to the multileveled approach to problem solving, which translates to increased reliability of the results and shortens the duration of the valuation process.

Despite the fact that the research was conducted individually on separate real properties, the methodology adopted here can be also successfully applied to the analysis of the physical characteristics of the set of the real properties located within an entire real estate market for which it can be assumed that the impact and importance of individual characteristics are the same,, thus one can model the impact of individual characteristics on the final value of the property (ŠUBIC, KOVAČ, RAKAR 2008; SMODIŠ 2011).

\section{References}

BENDIG J., BOLTEN A., BARETH G., 2012, Introducing a low-cost mini-UAV For thermal-and multispectralimaging", International Archives of the Photogrammetry, Remote Sensing and Spatial Information Sciences, v.XXXIX-B1.

CHUVIECO E., 1989, Application of remote sensing and geographic information systems to forest fire hazard mapping, Remote Sensing of Environment, v.29(2), pp.147-159.

DĄBROWSKI R., ORYCH A., WALCZYKOWSKI P., 2010 Ocena możliwości wykorzystania wysokorozdzielczych zobrazowań satelitarnych w rozpoznaniu obrazowym", Archiwum Fotogrametrii, Kartografii i Teledetekcji, v.21, pp.75-86. (Evaluation of high resolution satellite imagery in image reconnaissance, Archives of Photogrammetry, Cartography And Remote Sensing, 2010, v.21, pp. $75-86$. 
DĄBROWSKI R., ORYCH A., WALCZYKOWSKI P., 2013, Evaluation of the possibility of using the miniMCA multispectral camera in Imagery Intelligence, Publishing Institution of the University of Zilina. Slovakia,pp. $111-115$.

Din A., HoESLI DiN A., HoESLI M., BENDER A., 1997, Environmental variables and real estate prices The Journal of Real Estate Finance and Economics 01/1997; 14(1-2), pp.189-202.

GAWRON H., 2012, Wpływ cech fizycznych działek na ceny gruntów budowlanych w aglomeracji miejskiej (na przykładzie aglomeracji poznańskiej), Studia i materiały Towarzystwa Naukowego Nieruchomości, v.20(2), pp.47-58. The influence of plots' physical attributes on building land prices in urban agglomerations (on the example of Poznan agglomeration), REAL ESTATE MANAGEMENT AND VALUATION, 2012, v.20(2), pp.47-58).

KOZIOŁ-KACZOREK D., 2012, Hierarchizacja cech nieruchomości z zastosowaniem analitycznego procesu hierarchicznego; Studia i materiały Towarzystwa Naukowego Nieruchomości, v.20(1), pp.165-174. Analytic hierarchy process and characteristics of real estate. Real Estate Management and Valuation, 2012, v.20(1), pp.165-174).

LATOS D., 2012, Dane geodezyjne jako podstawa weryfikacji informacji o nieruchomościach w aspekcie ich wykorzystania w systemie zarządzania nieruchomościami Policji; Studia i materiały Towarzystwa Naukowego Nieruchomości, v.20(4), pp. 203-212. (Real estate data sources and their verification due to exploitation of the data in GIS management system for state real estate, REAL ESTATE MANAGEMENT AND VALUATION, 2012, v.20(4), pp.203-212).

MetTernicht A. G., HURni L., GOGU R., 2005, An analysis of the potential contribution to geo-spatial systems for hazard assessment in mountainous environments, Remote Sensing of Environment 98(2005) pp:284 - 303.

RADZEWICZ A., WIŚNIEWSKI R., 2012, Zmienne, cechy i atrybuty nieruchomości; Studia i materiały Towarzystwa Naukowego Nieruchomości, v.20(1), pp.5-16 (Variables, features and attributes of real estate, Real Estate Management and Valuation, 2012, v.20(1), pp.5-16).

Ryan R., BAldridge, B., Schowengerdt R. A., ChOi T., Helider, D. L., BlOnSKI, S., 2003, IKONOS spatial resolution and image interpretability characterization, Remote Sensing of Environment, 88(01), pp. 37-52.

SMODIŠ M.,2011, Completion of the implementation of the real estate mass valuation system, Geodetski, Vestnik v.55/2011 No. 2.

ŠUBIC KOVAČ M., RAKAR A., 2008, Information required for single real estate valuation Geodetski, Vestnik v.5/2008(4), pp.706-715.

Ustawa prawo geodezyjne i kartograficzne z dnia 17 maja 1989r. Dz.U. 1989 nr 30 poz. 163 z późn. Zmianami. The Act of 17 May 1989 of Geodetic and Cartographic Law, Journal of Laws, 1989, No. 30, item 163, as amended. 